\title{
Hydrological modeling of the Peruvian-Ecuadorian Amazon Basin using GPM-IMERG satellite-based precipitation dataset
}

\author{
Ricardo Zubieta $^{1,2}$, Augusto Getirana ${ }^{3,4}$, Jhan Carlo Espinoza ${ }^{1,2}$, Waldo Lavado-Casimiro ${ }^{5,2}$, and Luis Aragon ${ }^{2}$ \\ ${ }^{1}$ Subdirección de Ciencias de la Atmósfera e Hidrósfera (SCAH), Instituto Geofísico del Perú (IGP), Lima, Peru \\ ${ }^{2}$ Programa de Doctorado en Recursos Hídricos, Universidad Nacional Agraria La Molina, Peru \\ ${ }^{3}$ Hydrological Sciences Laboratory, NASA Goddard Space Flight Center, Greenbelt, MD, USA \\ ${ }^{4}$ Earth System Science Interdisciplinary Center, College Park, MD, USA \\ ${ }^{5}$ Servicio Nacional de Meteorología e Hidrología (SENAMHI), Lima, Peru \\ Correspondence to: Ricardo Zubieta (rzubieta@igp.gob.pe)
}

Received: 12 December 2016 - Discussion started: 14 December 2016

Revised: 7 March 2017 - Accepted: 1 June 2017 - Published: 14 July 2017

\begin{abstract}
In the last two decades, rainfall estimates provided by the Tropical Rainfall Measurement Mission (TRMM) have proven applicable in hydrological studies. The Global Precipitation Measurement (GPM) mission, which provides the new generation of rainfall estimates, is now considered a global successor to TRMM. The usefulness of GPM data in hydrological applications, however, has not yet been evaluated over the Andean and Amazonian regions. This study uses GPM data provided by the Integrated Multi-satellite Retrievals (IMERG) (product/final run) as input to a distributed hydrological model for the Amazon Basin of Peru and Ecuador for a 16-month period (from March 2014 to June 2015) when all datasets are available. TRMM products (TMPA V7 and TMPA RT datasets) and a gridded precipitation dataset processed from observed rainfall are used for comparison. The results indicate that precipitation data derived from GPM-IMERG correspond more closely to TMPA V7 than TMPA RT datasets, but both GPM-IMERG and TMPA V7 precipitation data tend to overestimate, compared to observed rainfall (by 11.1 and $15.7 \%$, respectively). In general, GPM-IMERG, TMPA V7 and TMPA RT correlate with observed rainfall, with a similar number of rain events correctly detected $(\sim 20 \%)$. Statistical analysis of modeled streamflows indicates that GPM-IMERG is as useful as TMPA V7 or TMPA RT datasets in southern regions (Ucayali Basin). GPM-IMERG, TMPA V7 and TMPA RT do not properly simulate streamflows in northern regions (Marañón and Napo basins), probably because of the lack of
\end{abstract}

adequate rainfall estimates in northern Peru and the Ecuadorian Amazon.

\section{Introduction}

Satellite-based precipitation data have been widely used for hydrometeorological applications, such as hydrological modeling, especially in data-sparse regions like the Amazon River basin (Collischonn et al., 2008; Getirana et al., 2011; Paiva et al., 2013; Zulkafli et al., 2014; Zubieta et al., 2015). Rainfall is extremely variable in both space and time, particularly over regions characterized by topographic contrast, such as the western Amazon Basin (Espinoza et al., 2009; Lavado et al., 2012). In this region, the Andes Mountains contribute to high spatiotemporal variability of rainfall (Laraque et al., 2007; Espinoza et al., 2015). To improve approximation and reduce uncertainty, detailed monitoring is needed using a high-density rain gauge network. Only a lowdensity rain gauge network is available in the Amazon Basin $(\mathrm{AB})$, however, which limits understanding of hydrological processes and hydrological modeling over the region (Getirana et al., 2011; Paiva et al., 2013). Satellite-based datasets, uniformly distributed in both space and time, offer an alternative for modeling hydrological events. Their usefulness in Andean-Amazon basins and their applicability as input to hydrological models have been evaluated recently by comparing modeled and observed datasets. Results indicate that these datasets could be used for operational applications in 
some Andean-Amazon regions (Zulkafli et al., 2014; Zubieta et al., 2015). However, hydrological modeling using satellite-based precipitation data does not yield successful results in equatorial regions. This is mainly because of inadequate satellite estimates, because streamflows resulting from hydrological modeling using observed rainfall show acceptable performance in the Napo River basin in the equatorial region (Zubieta et al., 2015).

Hydrological modeling and forecasting are still poorly developed in the Andean and Amazonian regions. It is important to improve these tools, especially because of an intensification of extreme hydrological events in the Amazon Basin (Gloor et al., 2013), such as intense droughts in 2005 and 2010 (Marengo et al., 2008, 2011; Espinoza et al., 2011) and severe floods in 2009, 2012 and 2014 (Espinoza et al., 2012, 2013, 2014). Moreover, a high percentage of total annual precipitation can fall in just a few days, causing soil erosion and landslides (Zubieta et al., 2017)

In the last two decades, advances in satellite technology have improved rainfall estimation in much of the world (Huffman et al., 2007). The Tropical Rainfall Measuring Mission (TRMM) Multi-satellite Precipitation Analysis (TMPA) precipitation dataset (Huffman et al., 2007) has been important for research and for many hydrological applications in Amazon regions, and there is consensus among studies using TMPA in Amazon regions (Collischonn et al., 2008; Getirana et al., 2011; Paiva et al., 2013; Zulkafli et al., 2014; Zubieta et al., 2015). The TRMM mission ended on 8 April 2015, however, after the spacecraft depleted its fuel reserves (https://pmm.nasa.gov/trmm/mission-end). Despite TRMM's demise, this is not a substantive issue for some products, such as TMPA and TMPA-RT, which are expected to run in parallel with the new Global Precipitation Measurement (GPM) satellite until mid-2017 (Huffman et al., 2015). The GPM mission (Schwaller and Morris, 2011), launched in February 2014, comprises an international constellation of satellites that provide rainfall estimations with significant improvements in spatiotemporal resolution, compared to TMPA products. This is true of GPM products such as Integrated Multi-satellite Retrievals (IMERG) estimations. Recent studies highlight that the GPM-IMERG estimations can adequately substitute for TMPA estimations both hydrologically and statistically, despite limited data availability (Liu, 2016; Tang et al., 2016).

The aim of this paper is to evaluate the use of rainfall estimates from GPM-IMERG for obtaining streamflows over the Amazon Basin of Peru and Ecuador (ABPE) during a 16month period (from March 2014 to June 2015) for which all datasets are available. It provides a comparative analysis of the GPM-IMERG, TMPA RT and TMPA V7 datasets and a ground-based precipitation dataset (PLU). PLU was developed by spatial interpolation using the Peruvian National Meteorology and Hydrology Service (SENAMHI) network. Each precipitation dataset was used as input for the MGB-
IPH hydrological model (Collischonn et al., 2007), which was recently adapted to the ABPE (Zubieta et al., 2015).

The ABPE extends from the tropical Andes to the Peruvian Amazon, with elevations ranging up to $6300 \mathrm{~m}$ above sea level, a drainage area of $878300 \mathrm{~km}^{2}$ and a mean discharge of $\sim 35500 \mathrm{~m}^{3} \mathrm{~s}^{-1}$ at the Tabatinga station (Lavado et al., 2012). The ABPE is located in the northwestern AB (Fig. 1a), and its area corresponds to $14 \%$ of the AB. It consists mainly of basins such as the Ucayali Basin (southern ABPE), Marañón Basin (west of the ABPE) and Napo Basin (northern ABPE) (Fig. 1b).

\section{Datasets used}

GPM is an international US-Japanese Earth science mission involving NASA and JAXA, respectively. The GPM mission improved and expanded on TRMM. GPM and TRMM provide precipitation data derived from different passive microwave (PMW) sources used in IMERG and TMPA, respectively (Huffman et al., 2015), including the Sounder for Atmospheric Profiling of Humidity in the Intertropics by Radiometry (SAPHIR), Advanced Technology Microwave Sounder (ATMS), Atmospheric Infrared Sounder (AIRS), Cross-Track Infrared Sounder (CRIS), and TRMM Combined Instrument (TCI) algorithms (2B31). They also include TRMM Microwave Image (TMI, data ended on 8 April 2015), GPM Microwave Imager (GMI), Advanced Microwave Scanning Radiometer for Earth Observing Systems (AMSR-E), Special Sensor Microwave Imager/Sounder (SSMIS), Microwave Humidity Sounder (MHS), Special Sensor Microwave Imager (SSM/I), Advanced Microwave Sounding Unit (AMSU), Operational Vertical Sounder (TOVS) and microwave-adjusted merged geo-infrared (IR). The precipitation datasets used in this study are as follows:

a. GPM (product IMERG-V03D) data at several levels of processing have been provided since March 2014 (GPM-IMERG data are available at http://pmm.nasa. gov/GPM, NASA, 2016). The input precipitation estimates are computed using raw satellite measurements, such as those from passive microwave sensors (TMI, AMSR-E, SSM/I, SSMIS, AMSU, MHS, SAPHIR, GMI, ATMS, TOVS, CRIS and AIRS), inter-calibrated to the GPM Combined Instrument (GCI, using GMI and Dual-frequency Precipitation Radar, DPR) and adjusted with monthly surface precipitation gauge analysis data (where available). All these datasets are used to obtain the best estimate of global precipitation maps. The temporal resolution of IMERG-V03D is half-hourly, and it has a $0.1^{\circ}$ by $0.1^{\circ}$ spatial resolution. Unlike other satellites, such as TRMM, GPM-IMERG can detect both light and heavy rain and snowfall.

b. TMPA 3B42 version 7 is obtained from the preprocessing of data provided by different satellite-based sensors 

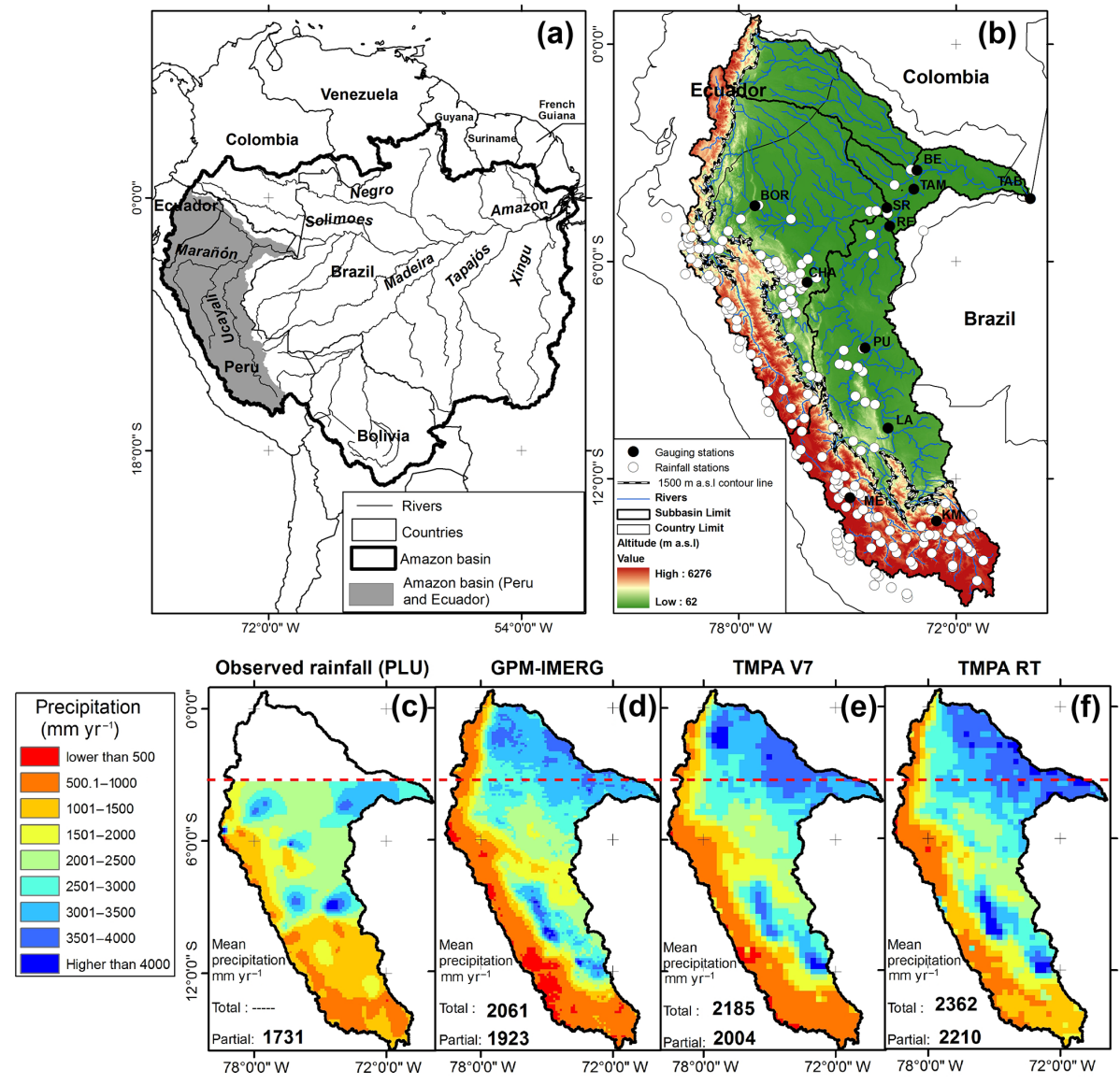

Figure 1. (a) Location of the Amazon Basin in South America. (b) The western Amazon Basin, gauging and rainfall stations used in this work; intermittent line represents main isohypse $1500 \mathrm{~m}$ a.s.l. Total annual precipitation estimated from (c) observed rainfall-PLU, (d) GPM-IMERG, (e) TMPA V7 and (f) TMPA RT over the Amazon Basin of Peru and Ecuador.

between 1998 and April 2015, in both real and nearreal time (TMPA 3b42 data are available at https://pmm. nasa.gov/data-access/downloads/trmm, NASA, 2017). The 3B42 algorithm (every $3 \mathrm{~h}$ ) combines precipitation estimates from TMI, AMSR, SSMIS, SSM/I, AMSU, MHS, TCI, MetOp-B and IR. After the preprocessing is complete, the 3-hourly multi-satellite estimations are summed for the month and combined with monthly rainfall obtained from the Global Precipitation Climatology Centre (GPCC), which uses ground-based precipitation. The last step is to scale each 3-hourly rainfall estimate for the month to sum to the monthly value (for each pixel separately, $0.25^{\circ}$ by $0.25^{\circ}$ spatial resolution).

c. TMPA RT (real time) precipitation data are related to TMPA V7, but do not include calibration measurements of rainy seasons, which are incorporated more than a month after the satellite data. (https://pmm.nasa.gov/ data-access/downloads/trmm, NASA, 2017). As with TMPA V7, the final, gridded, subdaily temporal resolution of TMPA RT is usually every 3 hours, with a $0.25^{\circ}$ by $0.25^{\circ}$ spatial resolution. d. To evaluate satellite-based datasets, a precipitation product was obtained using daily data series (PLU) from SENAMHI rainfall stations. We collected daily rainfall data for 202 rain stations during the selected period. Quality control based on the regional vector method (RVM) was used to select stations with the lowest probability of errors in their data series (Hiez, 1977; Brunet-Moret, 1979). Finally, 181 RVM-approved rainfall data series (distributed over $700000 \mathrm{~km}^{2}$ ) were selected, with data between March 2014 and June 2015 (Fig. 1b). The area with the highest data availability covers around $81 \%$ of the ABPE (the $19 \%$ without availability is mainly located in the northern region), where the largest distribution of rainfall stations is in the Andean regions, rather than Amazonian regions, of the Ucayali and Huallaga basins (the Huallaga is a subbasin of the Marañón Basin). For comparison, both regions with and without availability of rainfall data were considered for hydrological modeling. Rainfall observations were subsequently spatially interpolated to a resolution of $0.1^{\circ} \times 0.1^{\circ}$ by ordinary kriging, and a 
spherical semivariogram model was used to generate a gridded daily rainfall dataset. Data transformations and anisotropy were applied when necessary. This method has been used to interpolate environmental variables, such as rainfall in the Amazon and Andean regions (Guimberteau et al., 2012; Zubieta et al., 2017). To use each precipitation dataset as input to the hydrological model, subdaily data (for example, TMPA datasets with a temporal resolution of $3 \mathrm{~h}$ ) were rescaled to a daily time step.

To evaluate model results, streamflow series from the SO-HYBAM Observatory (www.ore-hybam.org, HYBAM, 2016) and SENAMHI stations for the selected period were used; these were KM105 (KM), Mejorada (ME), Chazuta (CHA), Borja (BO), Bellavista (BE), Lagarto (LA), Pucallpa (PU), Requena (RE), San Regis (SR), Tamshiyacu (TAM) and Tabatinga (TAB) (Fig. 1b, Table 1). To describe climate characteristics, meteorological data from NCEP-DOE Reanalysis at surface level (Kanamitsu et al., 2002) were collected, including relative humidity, wind speed, solar radiation, air temperature and atmospheric pressure. Basin topography is derived from the Shuttle Radar Topography Mission (SRTM, version 2). Digital thematic maps correspond to vegetation and soil maps of Peru (http://ref.data.fao.org/es/web/guest/map? entryId=dfcc42e0-88fd-11da-a88f-000d939bc5d8, FAO, 2016) and a vegetation-type map of Ecuador (http:// sociobosque.ambiente.gob.ec/files/Folletomapa-parte1.pdf,

Socio Bosque, 2016). A soil map of Ecuador (SECSEcuador, http://www.gifex.com/detail/2011-10-31-14743/ Mapa-General-de-Suelos-del-Ecuador-1986.html) and soil and land-use maps of Colombia (IGAC-Colombia, http://geoportal.igac.gov.co, IGAC-Colombia, 2016) were also considered. GPM-IMERG, TMPA V7, TMPA RT and PLU datasets were selected for the period corresponding to observed streamflows.

\section{Methodology}

The MGB-IPH model (Collischonn et al., 2007) has been used to simulate the hydrological behavior of the ABPE. It consists of modules for calculating soil water budget, evapotranspiration, flow propagation within a cell and flow routing through the drainage network. A HRU (hydrological response unit) (Kouwen et al., 1993) approach is used to perform soil water balance by mean spatial classification of all areas with a similar combination of soil and land cover. The benefit of using HRUs is the increased accuracy in streamflow simulations on smaller scales, as they make it possible to take better advantage of high spatial resolution databases for hydrological modeling applications. To create HRUs, the watershed is divided into regular elements (cells), which are interconnected by channels. A parameter set is calculated separately for each HRU of each pixel, considering only one layer of soil (Collischonn et al., 2007). The MuskingumCunge method is used for routing streamflows through the river network from runoff generated for different HRUs in the cells. Streamflows are adjusted for accuracy according to the stream-reach length and slope. A detailed description of the MGB-IPH model is provided in Collischonn et al. (2007).

The comparison of precipitation datasets was performed in two steps: first, an analysis of monthly averages and detected rain events at different precipitation thresholds $(0.1,1$, 5, 10 and $20 \mathrm{~mm} \mathrm{day}^{-1}$ ) was conducted over the ABPE. The analysis was performed by computing the frequency bias index (FBI), probability of detection (POD), false alarm ratio (FAR) and equitable threat score (ETS) (see Table 2). These are calculated from a $2 \times 2$ contingency matrix composed of four parameters $(a, b, c, d)$, where $a$ is the number of observed rain events correctly detected, $b$ is the number of observed rain events not detected, $c$ is the number of rainfall events detected but not observed (false alarms), and $d$ is the sum of cases in which neither observed nor detected rain events occurred. FBI allows analysis of overestimation or underestimation of rain events, POD provides information about sensitivity to non-detected and detected events, FAR is a function of false alarms, and ETS indicates the fraction of observed and/or detected rain events that were correctly detected. Comparison of rainfall estimates (GPM-IMERG, TMPA RT) to PLU has been also performed using the Heidke skill score (HSS). HSS is based on the number of correctly predicted data in which the category with the largest probability proves to be correct, as reflected in the formula: HSS $=\frac{C-E}{N-E}$, where $C$ is the number of correct predictions, $E$ is the number of correct predictions expected by chance and $N$ is the total number of predictions. HSS $=1$ refers to a perfect prediction, HSS $=0$ shows no skill and HSS $<0$, indicates that a prediction is worse than a random prediction.

Two performance coefficients were then used to evaluate the streamflow simulations: the Nash-Sutcliffe (NS) coefficient, and the difference between volumes calculated and observed $(\Delta V)$, shown in Eqs. (1) and (2):

$$
\begin{gathered}
\mathrm{NS}=1-\frac{\sum_{t=1}^{n t}\left(Q_{\mathrm{obs}}(t)+Q_{\mathrm{cal}}(t)\right)^{2}}{\sum_{t=1}^{n t}\left(Q_{\mathrm{obs}}(t)-\overline{Q_{\mathrm{obs}}}\right)^{2}}, \\
\Delta V=\frac{\sum\left(Q_{\mathrm{obs}}(t)\right)-\sum\left(Q_{\mathrm{obs}}(t)\right)}{\sum\left(Q_{\mathrm{obs}}(t)\right)},
\end{gathered}
$$

with $Q_{\text {obs }}$ observed and $Q_{\text {cal }}$ modeled streamflows. The range of efficiency lies from $-\infty$ to 1 . An efficiency of 1 $\left(E_{\mathrm{f}}=1\right)$ corresponds to a perfect fit of modeled streamflow and observed data, while an efficiency of less than zero indicates that the mean value of the time series (observed) would have been a better predictor than the model. A Taylor diagram was used to provide a graphic summary of how closely a pattern (or a set of simulated streamflows) matches observed streamflows. In this diagram, the similarity among three statistical patterns is quantified according to the amplitude of their coefficient of variation (CV\%), correlation coef- 
Table 1. Characteristics of streamflow gauging stations in the Amazon Basin of Peru and Ecuador: altitude, river, drainage area, annual mean streamflow $\left(Q_{\text {mean }}\right)$, maximum streamflow $\left(Q_{\max }\right)$ and minimum streamflow $\left(Q_{\min }\right)$ in cubic meters per second.

\begin{tabular}{llrlrrrr}
\hline$N$ & Station & Altitude & River & Area $\left(\mathrm{km}^{2}\right)$ & $Q_{\text {mean }}\left(\mathrm{m}^{3} \mathrm{~s}^{-1}\right)$ & $Q_{\max }\left(\mathrm{m}^{3} \mathrm{~s}^{-1}\right)$ & $Q_{\min }\left(\mathrm{m}^{3} \mathrm{~s}^{-1}\right)$ \\
\hline 1 & KM105 (KM) & 2275 & Ucayali & 9635 & 98 & 446 & 30 \\
2 & Mejorada (ME) & 2799 & Ucayali & 16930 & 186 & 651 & 76 \\
3 & Chazuta (CHA) & 226 & Marañon & 68685 & 3430 & 8921 & 936 \\
4 & Borja (BOR) & 163 & Marañon & 92302 & 6123 & 13250 & 1931 \\
5 & Bellavista (BE) & 90 & Napo & 100169 & 9338 & 13110 & 4654 \\
6 & Lagarto (LA) & 200 & Ucayali & 191428 & 6194 & 30460 & 1292 \\
7 & Pucallpa (PU) & 141 & Ucayali & 260418 & 10833 & 21830 & 3714 \\
8 & Requena (RE) & 94 & Ucayali & 350215 & 13669 & 20910 & 4088 \\
9 & San Regis (SR) & 92 & Marañon & 359883 & 20119 & 26610 & 9071 \\
10 & Tamshiyacu (TAM) & 88 & Amazon & 682970 & 37380 & 53840 & 15000 \\
11 & Tabatinga (TAB) & 62 & Solimões & 878141 & 45384 & 62190 & 19700 \\
\hline
\end{tabular}

Table 2. Summary of rain event detection coefficients.

\begin{tabular}{lllrr}
\hline Coefficient & Name & Equation* & Range & Optimal score \\
\hline FBI & Frequency bias index & FBI $=(a+b) /(a+c)$ & $0-\infty$ & 1 \\
POD & Probability of detection & POD $=a /(a+c)$ & $0-1$ & 1 \\
FAR & False alarm ratio & FAR $=c /(a+c)$ & $0-1$ & 0 \\
ETS & Equitable threat score & ETS $=(a+\mathrm{He}) /(a+b+c-\mathrm{He})$ & $-\infty$ to 1 & 1 \\
\hline
\end{tabular}

$* \mathrm{He}=(a+b) \cdot(a+c) / N$ where $N$ is the total number of estimates.

ficient and centered root-mean-square difference (RMSD \%) (Taylor, 2001). This can be used to analyze the relative ability of hydrological models to simulate the spatial pattern of mean streamflow.

\section{Results}

\subsection{Ground-based precipitation dataset (PLU)}

To evaluate the ability of PLU to reproduce rainfall gradients in the Andes, the relationship between annual rainfall and altitude for 181 stations was compared. In this area, 100 rainfall stations are located above $2000 \mathrm{~m}$ a.s.l.; some record in excess of $1500 \mathrm{~mm}_{\text {year }}{ }^{-1}$, while less than $1200 \mathrm{~mm}_{\text {year }}{ }^{-1}$ is generally recorded above $3000 \mathrm{~m}$ a.s.l. At lower elevations, abundant rainfall is associated with warm, moist air and the release of a large quantity of water vapor over the first eastern slope of the Andes; as a result, the amount of rainfall decreases with altitude (Laraque et al., 2007; Espinoza et al., 2009). A group of 15 observed rainfall stations located above $2000 \mathrm{~m}$ a.s.l. show rainfall amount below $450 \mathrm{~mm}$ year $^{-1}$; this group cannot be adequately represented by PLU. Despite these differences, PLU and observed average rainfall show similar behavior at similar altitudes (Fig. S1 in the Supplement). Indeed, the observed average rainfall for 181 stations shows high correlation with PLU for the 2014-2015 period $(r=0.77 p<0.01$; Fig. S2a). In contrast, observed average rainfall shows lower correlation with GPM-IMERG,
TMPA V7 and TMPA RT (0.6, 0.56 and 0.61 , respectively; Fig. S2b-d).

\subsection{Comparison of GPM-IMERG and other rainfall datasets}

Total annual rainfall over the ABPE during the selected period, using all four precipitation products, is shown in Fig. 1c-f. The satellite-based datasets (GPM-IMERG, TMPA V7 and TMPA RT) produce overestimates compared to observation (PLU) during this period (by 11.1, 15.7 and $27.7 \%$, respectively). As Fig. 1c-f show, the satellite-based products present similar spatial distributions. These products are comparable to PLU over (a) the Andean regions (for this paper, the Andean and Amazon regions are considered to be above and below $1500 \mathrm{~m}$ a.s.l., respectively; see Fig. 1b), with precipitation mainly between 500 and $1500 \mathrm{~mm} \mathrm{year}^{-1}$, and (b) the northern Amazon regions (3.0-6. $\left.0^{\circ} \mathrm{S}\right)$, with precipitation between 2000 and $3000 \mathrm{~mm}_{\text {year }}{ }^{-1}$. There are some spatial differences over the southern Amazon regions. This can be attributed to greater uncertainty of the PLU dataset, however, because there are fewer rainfall stations in those regions, particularly the eastern Ucayali Basin (Fig. 1b).

A comparison of monthly rainfall over the Ucayali and Huallaga river basins (at the Requena and Chazuta stations) with satellite-based precipitation data during the selected period is shown in Figs. 2a and 3a. In these basins, spatial distribution of rainfall stations is greater in the Andes re- 

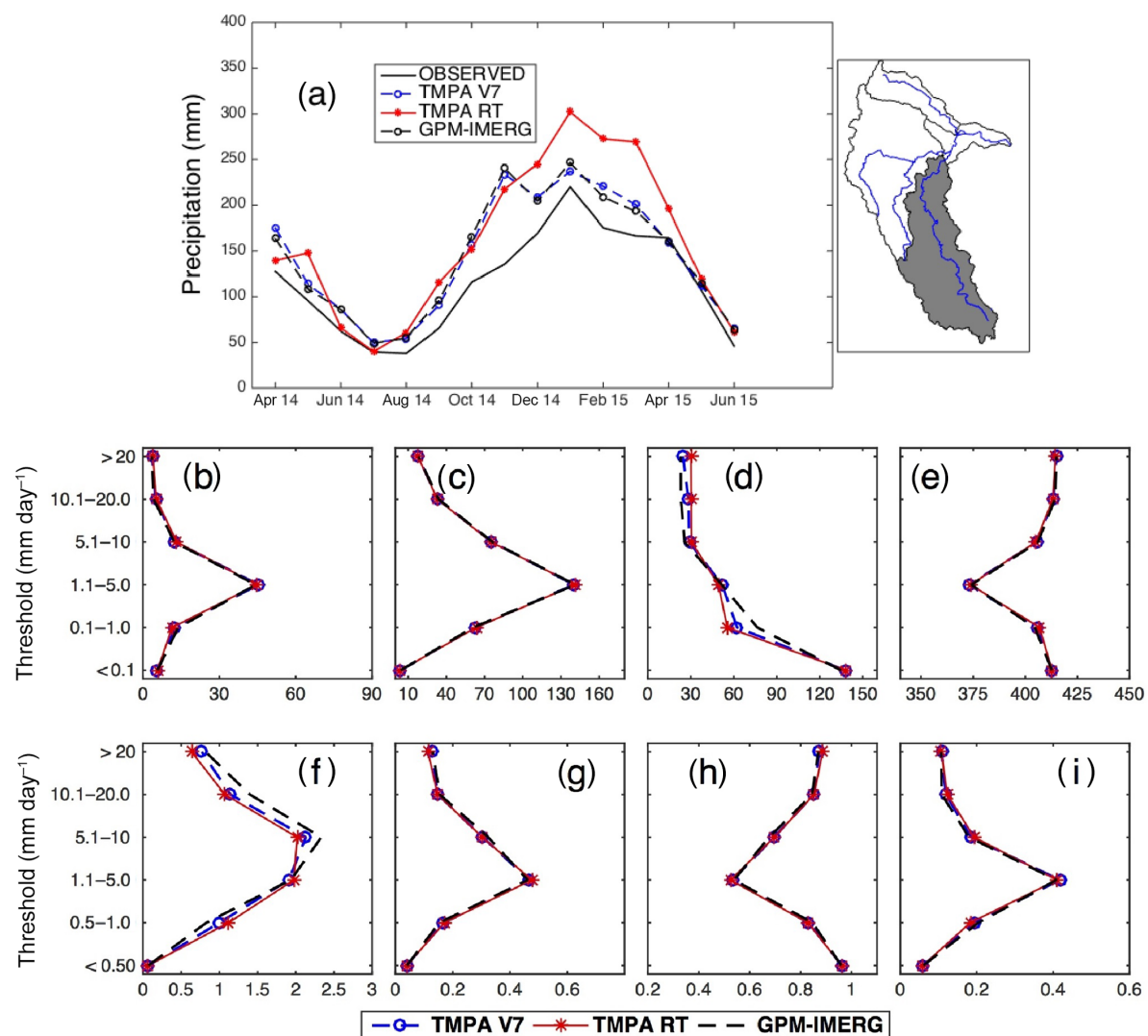

Figure 2. (a) Basin-average monthly rainfall for each precipitation dataset in the Ucayali Basin up to Requena station, (b) the number of observed rain events correctly detected, (c) the number of observed rain events not correctly detected, (d) the number of rain events detected but not observed (false alarms), (e) the sum of cases when neither observed nor detected rain events occurred, (f) coefficient frequency bias index (FBI), (g) probability of detection (POD), (h) false alarm ratio (FAR) and (i) equitable threat score (ETS).

gion than the Amazon region. The TMPA V7 and GPMIMERG datasets are very similar to each other in the Ucayali and Huallaga river basins. A monthly rainfall analysis shows that TMPA V7 and GPM-IMERG tend to overestimate dryseason rainfall in the Ucayali Basin (April to September) by $10.6 \%$, compared to the PLU dataset (Fig. 2a). Both datasets tend to overestimate wet-season rainfall, by $23 \%$, compared to the PLU dataset. This overestimation is larger than that obtained by TMPA V7 or GPM-IMERG when TMPA RT is analyzed (44\%). The GPM-IMERG, TMPA V7 and TMPA RT datasets tend to underestimate dry- and wet-season rainfall in the Huallaga Basin by $30.7,28.2$ and $26.2 \%$, respectively, compared to PLU (Fig. 3a).

Building on the average number of total days of rain events (456), the number of rain events correctly detected $(\sim 20 \%)$ is similar for each satellite precipitation dataset, compared to the PLU dataset, over the Ucayali and Huallaga basins (Figs. $2 \mathrm{~b}$ and $3 \mathrm{~b}$ ). The average number of events correctly and not correctly detected is also consistent - that is, all precipitation datasets are clearly better at identifying lowand moderate-precipitation events $\left(1-5 \mathrm{~mm} \mathrm{day}^{-1}\right)$ than the number of high- and very low-precipitation events (higher than $5 \mathrm{~mm} \mathrm{day}^{-1}$ and lower than $1 \mathrm{~mm} \mathrm{day}^{-1}$, respectively; Figs. $2 b-c$ and $3 b-c)$. Average FBI values obtained for all datasets indicate a low ability to detect rain events greater than $5 \mathrm{~mm} \mathrm{day}^{-1}$, producing FBI values varying mainly between 1 and 2 in the Ucayali and Huallaga basins. This differs substantially from optimal conditions $(\sim 1$; Figs. $2 \mathrm{f}$ and $3 \mathrm{f})$. This variation is due to the high number of rain events that were not correctly detected ( $\sim 80 \%$; Figs. $2 \mathrm{c}$ and $3 \mathrm{c})$. In general, the satellite-based datasets' limitation in representing rainfall may be due to their strong spatial variability in the Amazon-Andes region. The $\mathrm{AB}$ is distinguished by complex spatial distribution of rainfall because of the interactions between topography and large-scale humidity transport (Espinoza et al., 2015). High or extreme precipitation events can be variable in space and time, and the amount of rainfall recorded during extreme events in an Andean location may be normal in an Amazonian one.

Average POD values for all datasets indicate a moderate probability of detection (POD less than 0.55) of rain events greater than $5 \mathrm{~mm} \mathrm{day}^{-1}$; this probability decreases to $\sim 0.2$ for other events in the Ucayali and Huallaga basins (Figs. $2 \mathrm{~g}$ and $3 \mathrm{~g}$ ). The average number of events correctly and not cor- 

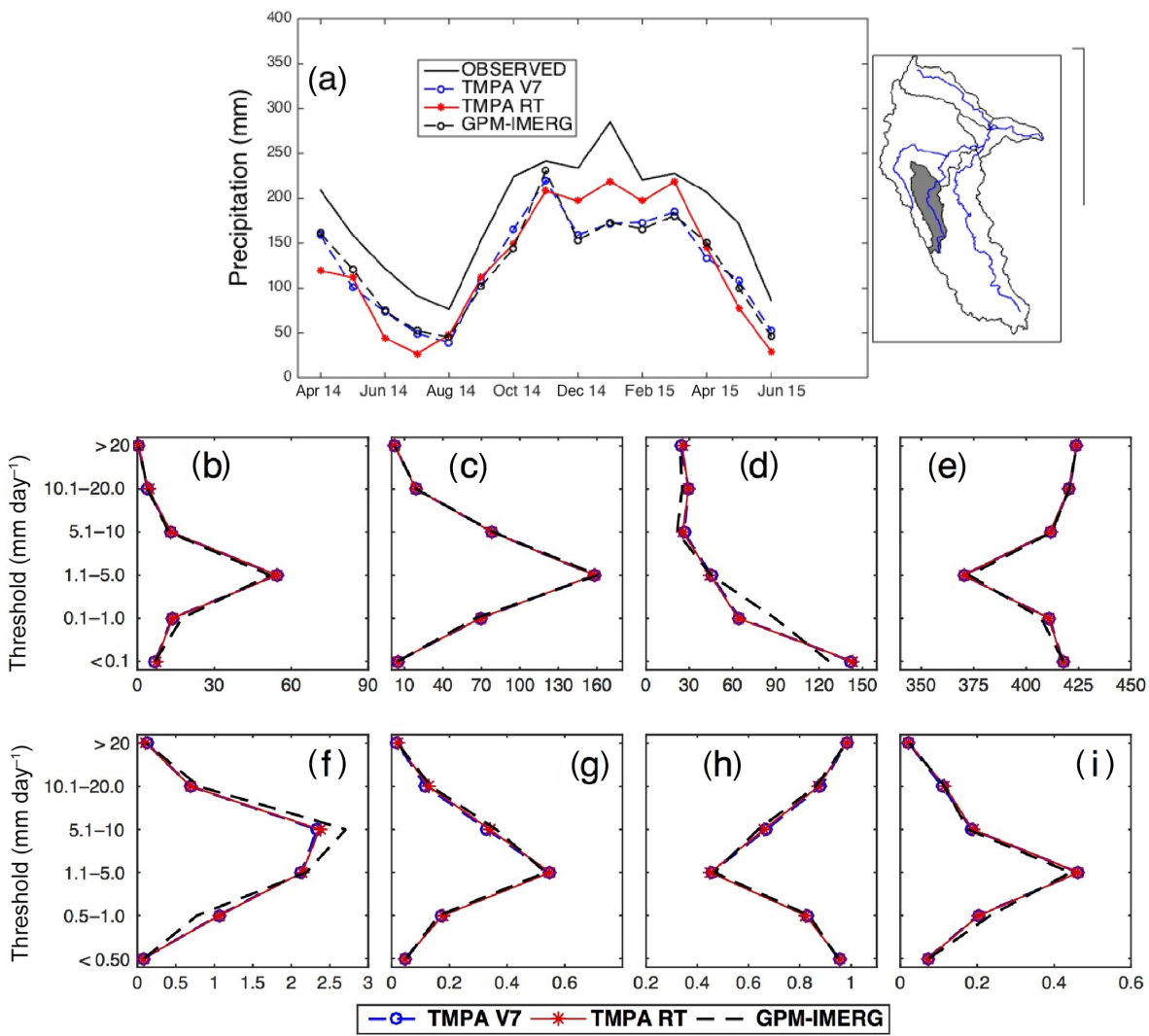

Figure 3. (a) Average monthly rainfall for each precipitation dataset in the Huallaga Basin up to the Chazuta station, (b) the number of observed rain events correctly detected, (c) the number of observed rain events not correctly detected, (d) the number of rain events detected but not observed (false alarms), (e) the sum of cases when neither observed nor detected rain events occurred, (f) coefficient frequency bias index (FBI), (g) probability of detection (POD), (h) false alarm ratio (FAR) and (i) equitable threat score (ETS).

rectly detected is also consistent - that is, all precipitation datasets are clearly better at identifying precipitation events of between 1 and $5 \mathrm{~mm} \mathrm{day}^{-1}$. The low probability of detection is consistent with the fraction of rain events that were correctly detected (Figs. 2i and 3i). This is due to a high false alarm rate of between $\sim 0.7$ and $\sim 0.9$ for rain events higher than $5 \mathrm{~mm} \mathrm{day}^{-1}$ and lower than $1 \mathrm{~mm} \mathrm{day}^{-1}$ for all satellite precipitation datasets in both the Ucayali and Huallaga basins (Figs. $2 \mathrm{~h}$ and $3 \mathrm{~h}$ ).

The limited ability to represent rainfall events of more than $5 \mathrm{~mm} \mathrm{day}^{-1}$ using satellite precipitation datasets (GPMIMERG, TMPA V7, TMPA RT), compared to PLU datasets (Figs. $2 \mathrm{~g}$ and $3 \mathrm{~g}$ ), may be due to overestimation (in the Ucayali Basin) or high overestimation (in the Huallaga Basin), identified mainly during the wet season (Figs. $2 \mathrm{a}$ and $3 \mathrm{a}$ ). Events exceeding $5 \mathrm{~mm}$ day $^{-1}$ are more likely to occur during that period.

The HSS spatial distribution estimated from daily precipitation using each satellite dataset (GPM-IMERG, TMPA V7 and TMPA RT) and PLU was calculated using thresholds $\left(0.1,1,5,10\right.$ and $\left.20 \mathrm{~mm} \mathrm{day}^{-1}\right)$ as a reference prediction (Fig. S3a-c). In general, for the daily scale, the HSS score varies between 0 and 0.4 , indicating low skill. The mean HSS for GPM-IMERG shows a moderate HSS score of around 0.4 in the northern region (Fig. S3a). The lowest HSS values (lower than 0.2) for GPM-IMERG are mainly located in the Andean regions, where there are more rainfall stations than in the Amazonian regions. This could be due to strong spatial variability, which is characterized by rainfall decrease with altitude and by the leeward or windward position of the stations (Espinoza et al., 2009). Low scores are also observed in more scattered areas along the ABPE when TMPA V7 and TMPA RT are analyzed (lower than 0.15). Nevertheless, this relationship is slightly improved in the northern region of the Ucayali Basin $(\sim 0.2)$.

\subsection{Streamflow simulation}

To optimize the simulation of streamflows from precipitation datasets, different parameter sets were assigned to each basin in the ABPE during calibration. Analysis by subbasin is more reliable than assigning the same parameter set to the entire basin (Zubieta et al., 2015). Based on sensitivity analysis of the MGB-IPH model (Collischonn et al., 2007), six parameters were selected for calibration: $\mathrm{Wm}(\mathrm{mm}), b(-), K_{\text {int }}$ 
Table 3. Model parameters subjected to the process of automatic calibration for the Peruvian and Ecuadorian Amazon Basin.

\begin{tabular}{|c|c|c|c|c|}
\hline Parameter & HRU & Hydrological process & First guess & Domain \\
\hline \multirow[t]{6}{*}{$\mathrm{Wm}(\mathrm{mm})$} & Shrubs, agricultural areas/not deep soils & Water storage on the HRU & 200 & $50-1200$ \\
\hline & Shrubs, agricultural areas/deep soils & & 400 & $50-1200$ \\
\hline & Forest/not deep soils & & 350 & $50-1200$ \\
\hline & Forest/deep soils & & 600 & $50-1200$ \\
\hline & Pasture/not deep soils & & 120 & $50-1200$ \\
\hline & Pasture/deep soils & & 240 & $50-1200$ \\
\hline \multirow{6}{*}{$K_{\text {int }}\left(\mathrm{mm} \mathrm{d}^{-1}\right)$} & Shrubs, agricultural areas/not deep soils & Subsurface flow & 80 & $50-150$ \\
\hline & Shrubs, agricultural areas/deep soils & & 90 & $50-150$ \\
\hline & Forest/not deep soils & & 100 & $50-150$ \\
\hline & Forest/deep soils & & 120 & $50-150$ \\
\hline & Pasture/not deep soils & & 70 & $50-150$ \\
\hline & Pasture/deep soils & & 80 & $50-150$ \\
\hline \multirow[t]{6}{*}{$K_{\text {bas }}\left(\mathrm{mm} \mathrm{d}^{-1}\right)$} & Shrubs, agricultural areas/not deep soils & Groundwater flow & 30 & $10-100$ \\
\hline & Shrubs, agricultural areas/deep soils & & 50 & $10-100$ \\
\hline & Forest/not deep soils & & 70 & $10-100$ \\
\hline & Forest/deep soils & & 80 & $10-100$ \\
\hline & Pasture/not deep soils & & 55 & $10-100$ \\
\hline & Pasture/deep soils & & 70 & $10-100$ \\
\hline $\mathrm{CS}$ & All & Surface flow & 15 & $0.35-40$ \\
\hline $\mathrm{CI}(-)$ & All & Subsurface flow & 120 & $1-200$ \\
\hline$b(-)$ & All & Variable infiltration curve & 0.12 & $0.01-2$ \\
\hline
\end{tabular}

$\left(\mathrm{mm} \mathrm{d}^{-1}\right), K_{\text {bas }}\left(\mathrm{mm} \mathrm{d}^{-1}\right), \mathrm{CS}(-)$ and $\mathrm{CI}(-)$, where Wm represents water retained in the soil, which influences the evaporation process over time; $K_{\text {int }}$ and $K_{\text {bas }}$ control the amount of water in cases in which subsurface soil and groundwater, respectively, are saturated; and CS and CI allow for adjustment of retention time of flows (Collischonn, 2001). To determine optimal parameters, an automatic calibration process was used in order to reduce the domain extent; a previous manual adjustment of the values was performed (Table 3). To ensure impartiality, parameter sets were calibrated separately for each precipitation dataset. Different domains were considered initially for each parameter value, and a first value, determined by manual calibration, was defined as the relative centroid for each domain. The MOCOM-UA multi-criteria global optimization algorithm (Yapo et al., 1998) was then used to find optimal solutions for six parameters. This process results in an effective and efficient search on the Pareto optimum space (Boyle et al., 2000). To analyze the impacts on the calibrated parameters, average parameters were calculated for precipitation datasets and HRU (Table 4).

The results of the calibration process indicate that overestimation by TMPA RT compared to observed rainfall (PLU), GPM-IMERG and TMPA V7 (Fig. 2a) in several months is consistent with a mean increase in $\mathrm{Wm}(+53,+6$ and $+15 \%$, respectively), along with a predominantly mean decrease in $K_{\text {bas }}\left(-18,-39\right.$ and $-16 \%$, respectively) and $K_{\text {int }}$ $(-25,-15$ and $+2 \%)$ to achieve water balance (Table 4$)$. Meanwhile, the overestimation by PLU compared to GPM-
IMERG, TMPA V7 and TMPA RT (Fig. 3a) is consistent with a mean increase in $W m(+33,+38$ and $+34 \%$, respectively), along with a mean decrease in $K_{\text {bas }}(-30,-28$ and $-38 \%$, respectively) and $K_{\text {int }}(-17,-16$ and $-17 \%)$ to achieve water balance (Table 4).

Resulting simulated streamflows were compared to observations at 11 gauging stations (Fig. 1b, Table 5). The Ucayali and Huallaga basins (with greater availability of rainfall gauges) and the northern region of the ABPE (without rainfall gauge availability) were considered in the comparative analysis. In general, streamflows obtained from all satellitebased precipitation datasets show the same spatial pattern as those obtained by using PLU (Fig. 4a-b) and are similar to those obtained by Zubieta et al. (2015). This study shows that GPM-IMERG can also be a helpful alternative source of data (similar to TMPA V7 and TMPA RT) for rainfallrunoff simulation in areas where conventional rainfall data is lacking, such as the Andean-Amazon regions of the Ucayali Basin. The performance analysis over the equatorial regions does not agree well with observed streamflows (NS lower than 0.60 ), probably because of the lack of adequate rainfall estimates. Similar results are obtained using the TMPA V7 (Fig. 4c) and TMPA RT (Fig. 4d) satellite precipitation datasets in the hydrological modeling.

Figure 5a-f shows the ability of the MGB-IPH model to simulate observed streamflows using TMPA V7, TMPA RT, GPM-IMERG and PLU precipitation datasets. Simulated streamflows match observations at six stations: (a) Chazuta 
Table 4. Values of the model mean parameters used in the Ucayali and Huallaga basins for each rainfall datasets for the 2014-2015 period.

\begin{tabular}{|c|c|c|c|c|c|c|c|c|c|}
\hline \multirow[b]{2}{*}{ Parameter } & \multirow[b]{2}{*}{$\mathrm{HRU}$} & \multicolumn{4}{|c|}{ Ucayali Basin } & \multicolumn{4}{|c|}{ Huallaga Basin } \\
\hline & & PLU & GPM-IMERG & TMPA V7 & TMPA RT & PLU & GPM-IMERG & TMPA V7 & TMPA RT \\
\hline \multirow[t]{6}{*}{$\mathrm{Wm}(\mathrm{mm})$} & Shrubs, agricultural areas/not deep soils & 268 & 351 & 294 & 373 & 100 & 60 & 65 & 60 \\
\hline & Shrubs, agricultural areas/deep soils & 340 & 472 & 503 & 597 & 132 & 102 & 96 & 99 \\
\hline & Forest/not deep soils & 300 & 408 & 273 & 344 & 130 & 101 & 99 & 96 \\
\hline & Forest/deep soils & 422 & 453 & 445 & 435 & 250 & 203 & 180 & 209 \\
\hline & Pasture/not deep soils & 144 & 350 & 261 & 321 & 101 & 60 & 66 & 59 \\
\hline & Pasture/deep soils & 196 & 400 & 454 & 496 & 150 & 120 & 116 & 121 \\
\hline \multirow{6}{*}{$\begin{array}{l}K_{\text {int }} \\
\left(\mathrm{mm} \mathrm{d}^{-1}\right)\end{array}$} & Shrubs, agricultural areas/not deep soils & 141 & 216 & 151 & 151 & 190 & 161 & 163 & 152 \\
\hline & Shrubs, agricultural areas/deep soils & 180 & 236 & 156 & 163 & 220 & 189 & 195 & 198 \\
\hline & Forest/not deep soils & 198 & 123 & 107 & 108 & 103 & 162 & 155 & 160 \\
\hline & Forest/deep soils & 200 & 134 & 108 & 113 & 120 & 208 & 199 & 220 \\
\hline & Pasture/not deep soils & 150 & 110 & 119 & 122 & 121 & 160 & 151 & 150 \\
\hline & Pasture/deep soils & 180 & 113 & 126 & 128 & 132 & 193 & 201 & 190 \\
\hline \multirow{6}{*}{$\begin{array}{l}K_{\text {bas }} \\
\left(\mathrm{mm} \mathrm{d}^{-1}\right)\end{array}$} & Shrubs, agricultural areas/not deep soils & 103 & 121 & 89 & 93 & 55 & 70 & 72 & 80 \\
\hline & Shrubs, agricultural areas/deep soils & 113 & 123 & 100 & 103 & 61 & 90 & 94 & 100 \\
\hline & Forest/not deep soils & 53 & 134 & 59 & 53 & 44 & 70 & 69 & 80 \\
\hline & Forest/deep soils & 62 & 25 & 69 & 62 & 63 & 90 & 88 & 100 \\
\hline & Pasture/not deep soils & 64 & 112 & 66 & 64 & 46 & 70 & 76 & 80 \\
\hline & Pasture/deep soils & 74 & 113 & 71 & 71 & 63 & 90 & 66 & 100 \\
\hline $\mathrm{CS}$ & All & 18 & 16 & 17 & 17 & 2.6 & 2.4 & 2.6 & 2.5 \\
\hline $\mathrm{CI}(-)$ & All & 112 & 111 & 118 & 111 & 111 & 133 & 135 & 132 \\
\hline$b(-)$ & All & 0.13 & 0.17 & 0.15 & 0.12 & 0.12 & 0.15 & 0.14 & 0.14 \\
\hline
\end{tabular}

Table 5. Summary of modeling results at 11 gauging stations in the Amazon Basin of Peru and Ecuador (to Tabatinga station in Brazil).

\begin{tabular}{|c|c|c|c|c|c|c|c|c|c|c|}
\hline \multirow[t]{2}{*}{$N$} & \multirow[t]{2}{*}{ River } & \multirow[t]{2}{*}{ Station } & \multicolumn{2}{|c|}{$\begin{array}{c}\text { Observed } \\
\text { rainfall (PLU) }\end{array}$} & \multicolumn{2}{|c|}{ GPM-IMERG } & \multicolumn{2}{|c|}{ TMPA V7 } & \multicolumn{2}{|c|}{ TMPA RT } \\
\hline & & & NS & $\Delta V$ & NS & $\Delta V$ & NS & $\Delta V$ & NS & $\Delta V$ \\
\hline 1 & Ucayali & KM105 (KM) & 0.82 & 0.33 & 0.90 & -0.25 & 0.80 & -2.78 & 0.68 & 11.55 \\
\hline 2 & Ucayali & Mejorada (ME) & 0.89 & 4.2 & 0.61 & -18.5 & 0.61 & -17.01 & 0.75 & -6.49 \\
\hline 3 & Ucayali & Chazuta (CHA) & 0.37 & -18.27 & -0.26 & -31.96 & -0.37 & -33.51 & -0.02 & -29.55 \\
\hline 4 & Ucayali & Borja (BOR) & - & - & -3.94 & -47.98 & -3.09 & -42.39 & -3.91 & -47.53 \\
\hline 5 & Ucayali & Bellavista (BE) & - & - & -2.17 & -7.14 & -18.24 & -32.64 & -20.93 & -35.46 \\
\hline 6 & Marañon & Lagarto(LA) & 0.74 & -9.52 & 0.71 & -0.13 & 0.80 & -0.49 & 0.81 & -0.18 \\
\hline 7 & Marañon & Pucallpa (PU) & 0.48 & -8.1 & 0.61 & -17.2 & 0.60 & -17.80 & 0.89 & -8.3 \\
\hline 8 & Marañon & Requena (RE) & 0.51 & -10.6 & -3.75 & -23.59 & -7.71 & -33.28 & -5.33 & -23.32 \\
\hline 9 & Napo & San Regis (SR) & - & - & -5.40 & -24.82 & -5.68 & -25.59 & -4.90 & -24.72 \\
\hline 10 & Amazon & Tamshiyacu (TAM) & - & - & -24.51 & -32.22 & -33.32 & -37.57 & -28.19 & -33.19 \\
\hline 11 & Solimões & Tabatinga (TAB) & - & - & -3.85 & -10.28 & -12.88 & -19.51 & -5.21 & -10.74 \\
\hline
\end{tabular}

(CHA), (b) KM105 (KM), (c) Lagarto (LA), (d) Mejorada (ME), (e) Pucallpa (PU) and (e) Requena (RE). The location of each dataset on the plot quantifies how closely the modeled streamflows match observed streamflows in terms of CV, correlation coefficient and RMSD.

Figure 5a shows a Taylor diagram for the Chazuta station (Huallaga Basin), where modeled streamflows from the PLU dataset agree better with observed streamflows $(r=0.84$, $p<0.01$, RMSD error ( $30 \%)$ and CV of $29 \%$ ) than do those using data from satellite products (TMPA RT, TMPA V7 and GPM-IMERG). Analysis of the two smallest subbasins (in the Ucayali Basin) controlled at the KM (Fig. 5b) and ME (Fig. 5c) stations shows a correlation pattern of $r=\sim 0.9$ with RMSD of $\sim 40 \%$ at KM and $24-40 \%$ at ME (Fig. 5b- c). These results indicate that the streamflows from PLU and TMPA RT are more similar to the observed streamflow series mainly at ME, with RMSD lower than $30 \%$. The streamflow series at both KM and ME have a high CV (40-80\%), due to rainfall seasonality.

Analysis of the largest subbasins (in the Ucayali Basin) controlled at the LA, PU and RE stations shows greater similarity among them for the four streamflow series obtained from precipitation datasets (Fig. 5d-f). Their significant correlation patterns are between 0.8 and $0.9(r>0.9$ at the PU station), and RMSD is mainly between 20 and $25 \%$ (PU and $\mathrm{RE}$ ). It should be noted that streamflow data series have a lower CV in the larger subbasins, such as LA, with CV of $55 \%$ (drainage area of $191400 \mathrm{~km}^{2}$ ); PU, with CV of $42 \%$ 


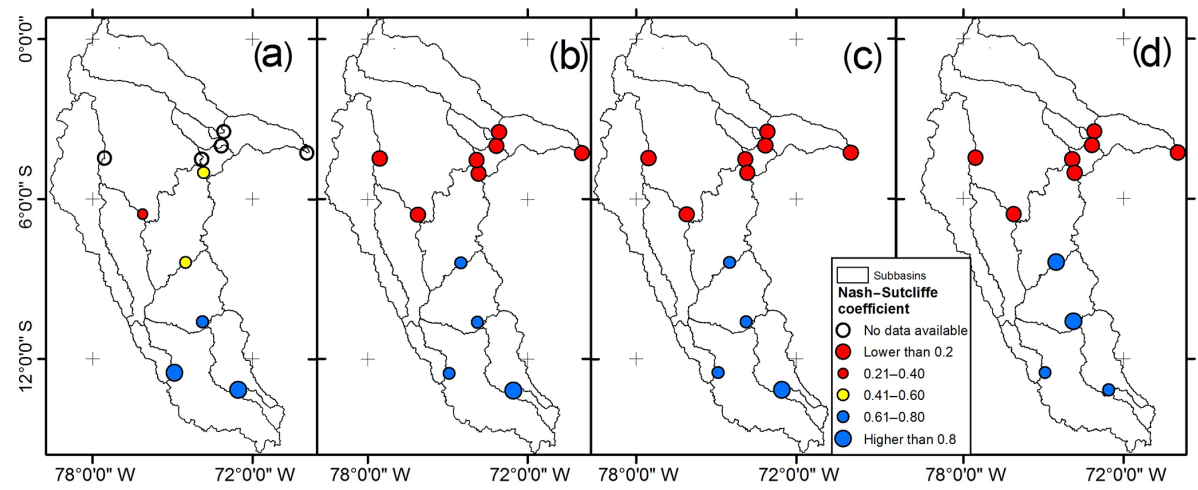

Figure 4. Nash-Sutcliffe efficiency coefficients map for simulations using (a) observed Rainfall (PLU), (b) GPM-IMERG, (c) TMPA V7 and (d) TMPA RT rainfall data.
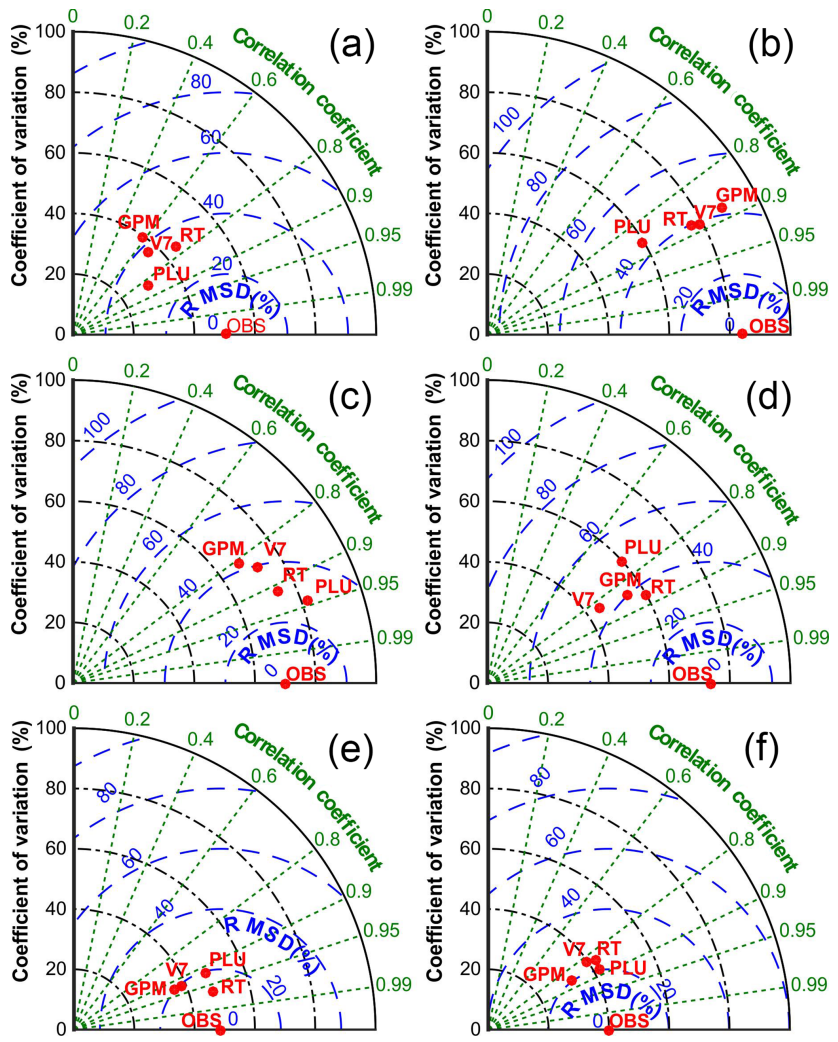

Figure 5. Taylor diagrams displaying a statistical comparison (coefficient of variation (\%), the root mean square difference $(\%)$ and correlation coefficient) between observed streamflows and modeled streamflows from four precipitation datasets (TMPA V7 (V7), TMPA RT (RT), GPM-IMERG (GPM), observed rainfall (PLU)) for six basins controlled at the following stations: (a) Chazuta (CHA), (b) KM105 (KM), (c) Mejorada (ME), (d) Lagarto (LA), (e) Pucallpa (PU) and (f) Requena (RE).

(drainage area of $260400 \mathrm{~km}^{2}$ ); and RE, with CV of $\sim 40 \%$ (drainage area of $350200 \mathrm{~km}^{2}$ ). This could be due to weaker seasonality of rainfall in the northern part of the basin. For simulations using satellite-based precipitation datasets, the correlation between simulated and observed streamflows is mainly between 0.6 and 0.9 , and RMSD is relatively high $(20-40 \%)$, suggesting that a hydrological model using these datasets can represent seasonal streamflows.

The PLU dataset used as input to the hydrological model produced good results at the KM105 (NS $=0.82$ and $\Delta V=$ $0.33 \%$; Fig. 6a), Mejorada (NS $=0.89$ and $\Delta V=4.2 \%$ ) and Lagarto (NS $=0.74$ and $\Delta V=-9.52 \%$ ) stations in the Ucayali Basin. This indicates its ability to represent extreme values (peak flow) with a low percentage of relative volume error $(\Delta V<10 \%)$. However, the model's performance is low at the Pucallpa and Requena stations (NS $<0.51$ and $\Delta V \sim 10 \%$ ), where its predictions are not accurate. The low performance $(\mathrm{NS}<0.60)$ is associated with drainage areas greater than the approximate threshold value of $200000 \mathrm{~km}^{2}$ in the Ucayali Basin. This could be due to greater uncertainty in the spatial distribution of rainfall in the Ucayali and Huallaga basins (northern region of the ABPE), because there are fewer rainfall stations in these regions. The Peruvian Andes are currently more instrumented than the Amazon regions (see Fig. 1b).

To analyze the usefulness of the GPM-IMERG datasets for hydrological modeling, hydrographs for the Ucayali Basin monitored at KM105 station (Fig. 6b) were analyzed, with streamflows from the PLU, TMPA V7 and TMPA RT datasets also considered (Fig. 6c-d). Visual analysis of the hydrographs shows that simulated streamflows using GPMIMERG for the selected period agree fairly well with observed streamflows for the KM105 station. Although the Nash-Sutcliffe efficiency coefficient is generally acceptable (NS $=0.90$ and $\Delta V=-0.25 \%$ ), as shown in Fig. 6b, there is a slight overestimation of streamflow during the wet season, which could be due to overestimation of rainfall during that season. Other results indicate that the model's performance is minimally acceptable in comparison to observed streamflow at the Pucallpa (NS $=0.61, \Delta V=-17.2 \%$; Fig. $6 \mathrm{~g}$ ) and Mejorada stations (NS $=0.61, \Delta V=-18.5 \%$ ). 

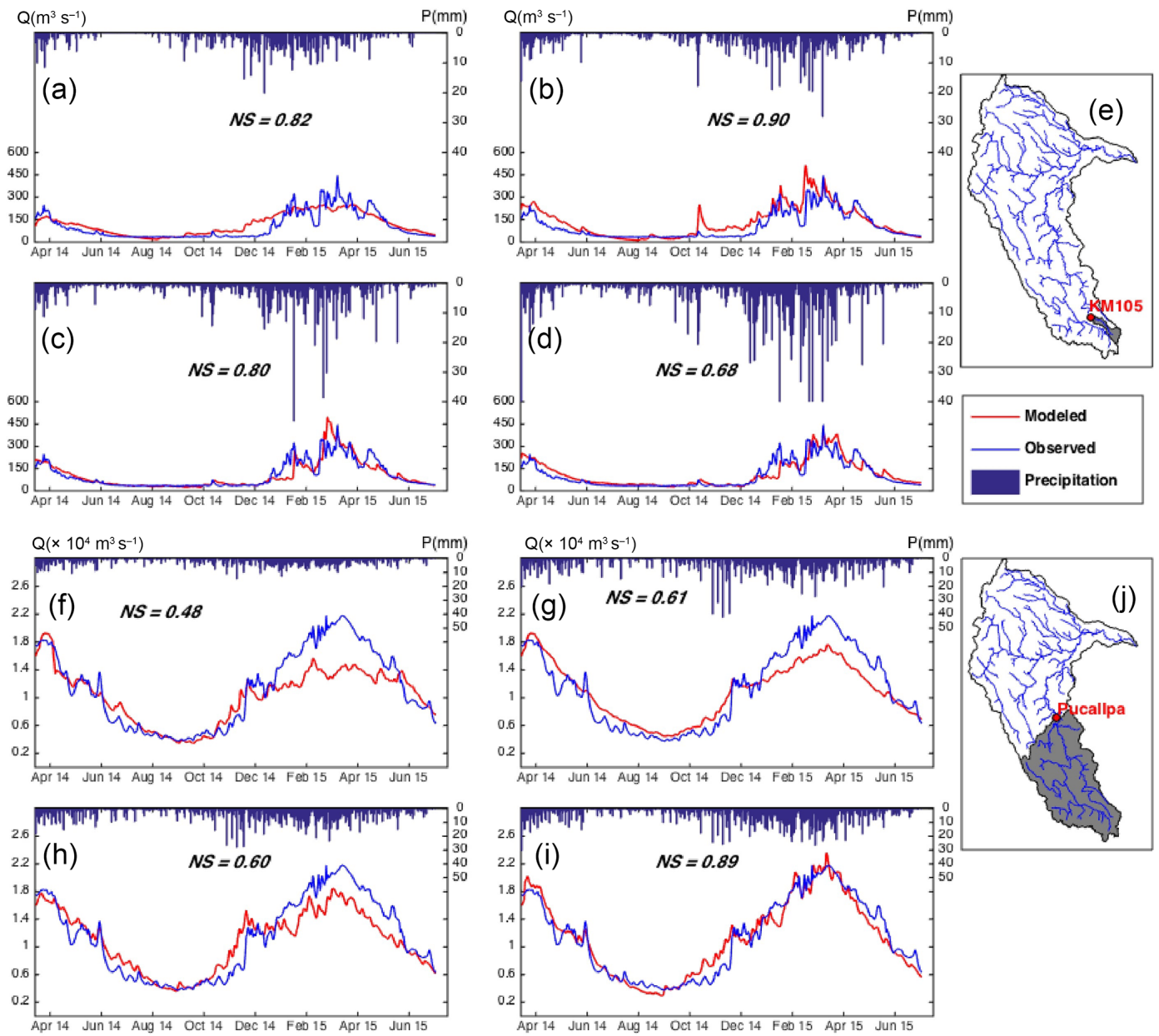

Figure 6. Observed and simulated streamflow hydrographs at KM105 station from 12 March 2014, to 30 June 2015, using the following precipitation datasets: (a) observed rainfall, (b) GPM-IMERG, (c) TMPA V7 and (d) TMPA RT. (e) Location of the drainage area controlled at the KM station. Observed and simulated streamflow hydrographs at the Pucallpa station from 12 March 2014, to 30 June 2015, using the following precipitation datasets: (f) observed rainfall, (g) GPM-IMERG, (h) TMPA V7 and (i) TMPA RT. (j) Location of the drainage area controlled at the Pucallpa station.

For the other stations, performance within the basin is less than zero.

Similar results were observed using TMPA V7 and TMPA RT, which reproduce the seasonal streamflow regime with similar performance at the KM105 $(\mathrm{NS}=0.80$ and $\Delta V=-2.78 \%, \mathrm{NS}=0.68$ and $\Delta V=11.5 \%$, respectively; Fig. 6c-d) and Pucallpa (NS $=0.60$ and $\Delta V=-17.8 \%$, $\mathrm{NS}=0.89$ and $\Delta V=-8.3 \%$, respectively) stations in the Ucayali Basin (Fig. 6h-i).

\section{Concluding Remarks}

Three satellite-based precipitation datasets (GPM-IMERG, TMPA V7 and TMPA RT) were evaluated against a raingauge-based dataset (PLU) obtained by spatial interpolation over the Amazon Basin of Peru and Ecuador. Each dataset was used as input for the MGB-IPH hydrological model to simulate streamflows for a 16-month period (from March 2014 to June 2015) in the Ucayali, Huallaga, Marañón, Napo, Amazon and Solimões river basins.

GPM-IMERG and TMPA V7 show high temporal and spatial similarity to PLU in the Ucayali Basin, but they tend to underestimate PLU in the Huallaga Basin during the wet season of the 2014-2015 period. TMPA RT tends to overestimate for the Ucayali Basin, compared to other precipitation datasets (PLU, TMPA V7 and GPM-IMERG), while it is more similar to other satellite-based precipitation datasets (TMPA V7 and GPM-IMERG) in the Huallaga Basin.

The GPM-IMERG dataset shows greater similarity to TMPA V7 than TMPA RT. This indicates that GPM-IMERG estimates are more similar to TMPA V7 both spatially and temporally when used as input for hydrological modeling over Andean and Amazonian basins. On average, rain event detection coefficients also suggest that GPM-IMERG, TMPA 
V7 and TMPA RT are similar to PLU in the number of rain events correctly detected $(\sim 20 \%)$ for the Ucayali and Huallaga basins. Analysis of rain events from pixel value comparing PLU and estimated daily rainfall (GPM-IMERG, TMPA V7 and TMPA RT) suggests a low capacity for detection. This does not imply that they are not useful for hydrological modeling, because rain events not correctly detected for a region or a day could be correctly detected on another day or in nearby regions, compensating for the estimation of rainfall amount over large regions.

In general, the performance of the model when using the GPM-IMERG dataset indicates that these data are useful for estimating observed streamflows in Andean-Amazonian regions (Ucayali Basin, southern regions of the Peruvian and Ecuadorian Amazon Basin). These results are similar to those obtained from TMPA V7 estimates by Zubieta et al. (2015) for the 2003-2009 period. Streamflows obtained from the GPM-IMERG, TMPA V7 and TMPA RT datasets show the same spatial pattern as those obtained by using PLU (low and high performance in the northern and southern regions of the ABPE, respectively). The ability to represent seasonal streamflows in the southern region using these four precipitation datasets is validated with statistical evaluation.

It is important to note that the advantages of GPM-IMERG over TMPA-V7 for estimating streamflows, such as temporal resolution ( $30 \mathrm{~min}$ compared to $3 \mathrm{~h}$, respectively), have not yet been fully analyzed. The use of subdaily rainfall data can be potentially useful for simulating discharge in the Andean rivers, where short convective rainfall episodes are more relevant for hydrological variability. In this study, precipitation and streamflows were analyzed at a daily time step. Further flash-flood modeling on smaller scales would reveal the effects of subdiurnal differences between datasets. Errors in streamflow simulations are mostly associated with input data uncertainty, including rainfall, limited representations of physical processes in models and parameters such as DEM and HRUs. Nevertheless, results show that it is possible to employ remote sensing data in large-scale hydrological models for streamflow simulations.

Data availability. All data used for this study can be found in Sect. 2.

\section{The Supplement related to this article is available online at https://doi.org/10.5194/hess-21-3543-2017- supplement.}

Competing interests. The authors declare that they have no conflict of interest.

Acknowledgements. The authors would like to thank SENAMHI for providing observed precipitation data series and the SO-HYBAM observatory for providing discharge data (www.ore-hybam.org). The authors also acknowledge GSFC/DAAC and PMM (NASA) for providing the TMPA (https://pmm.nasa.gov/data-access/downloads/trmm/) and GPMIMERG (http://pmm.nasa.gov/GPM) datasets, respectively. Finally, Ricardo Zubieta and Jhan Carlo Espinoza wish to acknowledge the PNICP-Peru for providing funds through contract 397-PNICPPIAP-2014.

Edited by: Niko Verhoest

Reviewed by: two anonymous referees

\section{References}

Boyle, D. P., Gupta, H. V., and Sorooshian, S.: Toward improved calibration of hydrologic models: combining the strengths of manual and automatic methods, Water Resour. Res., 36, 36633674, 2000.

Brunet-Moret, Y.: Homogénéisation des précipitations. Cahiers ORSTOM, Série Hydrologie, 16, 3-4, 1979.

Collischonn, W.: Hydrologic simulation of large basins (in Portuguese), PhD Thesis, Inst. de Pesqui. Hidraul., Univ. Fed. do Rio Grande do Sul, Porto Alegre, Brazil, 2001.

Collischonn, W., Allasia, D. G., Silva, B. C., and Tucci, C. E. M.: The MGB-IPH model for large-scale rainfall-runoff modeling, J. Hydrol. Sci., 52, 878-895, https://doi.org/10.1623/hysj.52.5.878, 2007.

Collischonn, B., Collischonn, W., and Tucci, C .: Daily hydrological modeling in the Amazon basin using TRMM rainfall estimates, J. Hydrol., 360, 207-216, https://doi.org/10.1016/j.jhydrol.2008.07.032, 2008.

Espinoza, J. C, Ronchail, J., Guyot, J. L., Cochonneau, G., Filizola, N. P., Lavado, C., De Oliveira, E., Pombosa, R., and Vauchel, P.: Spatio-Temporal rainfall variability in the Amazon basin countries (Brazil, Peru, Bolivia, Colombia and Ecuador), J. Climatol., 29, 1574-1594, https://doi.org/10.1002/joc.1791, 2009.

Espinoza, J. C., Ronchail, J., Guyot, J. L., Junquas, C., Vauchel, P., Lavado, W.S., Drapeau, G., and Pombosa, R.: Climate variability and extremes drought in the upper Solimões River (Western Amazon Basin): Understanding the exceptional 2010 drought, Geophys, Res. Lett., 38, L13406, https://doi.org/10.1029/2011GL047862, 2011.

Espinoza, J. C., Ronchail, J. Guyot, J. L., Junquas, C., Drapeau, G., Martinez, J. M., Santini, W., Vauchel, P., Lavado, W., Ordoñez, J., and Espinoza, R.: From drought to flooding: understanding the abrupt 2010-11 hydrological annual cycle in the Amazonas River and tributaries, Environ. Res. Lett., 7, 024008, https://doi.org/10.1088/1748-9326/7/2/024008, 2012.

Espinoza, J. C., Ronchail, J., Frappart, F., Lavado, W., Santini, W., and Guyot, J. L.: The major floods in the Amazonas River and tributaries (Western Amazon basin) during the 1970-2012 period: A focus on the 2012 flood, J. Hydrometeorol., 14, 10001008, https://doi.org/10.1175/JHM-D-12-0100.1, 2013.

Espinoza, J. C., Marengo, J. A., Ronchail, J., Molina, J., Noriega, L., and Guyot, J. L.: The extreme 2014 flood in south-western Amazon basin: The role of tropical-subtropical south Atlantic SST gradient, Environ. Res. Lett., 9, 124007, https://doi.org/10.1088/1748-9326/9/12/124007, 2014. 
Espinoza, J. C., Chavez, S., Ronchail, J., Junquas, C., Takahashi, K., and Lavado, W.: Rainfall hotspots over the southern tropical Andes: Spatial distribution, rainfall intensity and relations with large-scale atmospheric circulation, Water Resour. Res., 51, 3459-3475, https://doi.org/10.1002/2014WR016273, 2015.

Food and Agriculture Organization of the United Nations: http:// www.fao.org, last access: June 2016.

Getirana, A. C. V., Espinoza, J. C., Ronchail, J., and Rotunno, O.: Assessment of different precipitation datasets and their impacts on the water balance of the Negro River basin, J. Hydrol., 404, 304-322, https://doi.org/10.1016/j.jhydrol.2011.04.037, 2011.

Gloor, M. R. J. W., Brienen, D., Galbraith, T. R., Feldpausch, J., Schöngart, W., Guyot, J. L., Espinoza, J. C., Lloyd, J., and Phillips, O. L.: Intensification of the Amazon hydrological cycle over the last two decades, Geophys. Res. Lett., 40, 1729-1733, https://doi.org/10.1002/grl.50377, 2013.

Guimberteau, M., Drapeau, G., Ronchail, J., Sultan, B., Polcher, J., Martinez, J.-M., Prigent, C., Guyot, J.-L., Cochonneau, G., Espinoza, J. C., Filizola, N., Fraizy, P., Lavado, W., De Oliveira, E., Pombosa, R., Noriega, L., and Vauchel, P.: Discharge simulation in the sub-basins of the Amazon using ORCHIDEE forced by new datasets, Hydrol. Earth Syst. Sci., 16, 911-935, https://doi.org/10.5194/hess-16-911-2012, 2012.

Hiez, G.: L'homogénéité des données pluviométriques, Cahier ORSTOM, série Hydrologie, 14, 129-172, 1977.

Huffman, G., Adler, R., Bolvin, D., Gu, G., Nelkin, E., Bowman, K., Hong, Y., Stocker, E., and Wolff, D.: The TRMM Multisatellite Precipitation Analysis (TCMA): quasi-global, multiyear, combined- sensor precipitation estimates at fine scales, J. Hydrometeorol., 8, 38-55, https://doi.org/10.1175/JHM560.1, 2007.

Huffman, G. J., Bolvin, D. T., and Nelkin, E. J.: Day 1 IMERG Final Run Release Notes; NASA Goddard Earth Sciences Data and Information Services Center: Greenbelt, MD, USA, 2015.

HYBAM: HYBAM dataset, available at: www.ore-hybam.org/, last access: June 2016.

IGAC-Colombia: http://geoportal.igac.gov.co/, last access: January, 2013.

Kanamitsu, M., Ebisuzaki, W., Woolen, J., Yang, S. K., Hnilo, J. J., Fiorino, M., and Potter, G. L.: NCEP-DOE AMIPII Reanalysis (R-2), B. Am. Meteor. Soc., 83, 1631-1643, https://doi.org/10.1175/BAMS-83-11-1631, 2002.

Kouwen, N. and Mousavi, S. F.: WATFLOOD/SPL9: Hydrological model and flood forecasting system, in: Mathematical Models of Large Watershed Hydrology, edited by: Singh, V. P. and Frevert, D. K., Water Resources Publications, Highlands Ranch. Colorado, USA, 2002.

Kouwen, N., Soulis, E. D., Pietroniro, A., Donald, J., and Harrington, R. A.: Grouped response units for distributed hydrologic modelling, J. Water Resour. Plan.Manage., 119, 289-305, 1993.

Laraque, A., Ronchail, J., Cochonneau, G., Pombosa, R., and Guyot, J. L.: Heterogeneous distribution of rainfall and discharge regimes in the Ecuadorian Amazon basin, J. Hydrometeorol., 8, 1364-1381, https://doi.org/10.1175/2007JHM784.1, 2007.

Lavado, W., Labat, D., Ronchail, J., Espinoza, J. C., and Guyot, J. L.: Trends in rainfall and temperature in the Peruvian AmazonAndes basin over the last 40 years (1965-2007), Hydrol. Process., 27, 2944-2957, https://doi.org/10.1002/hyp.9418, 2012.
Liu, Z.: Comparison of Integrated Multisatellite Retrievals for GPM (IMERG) and TRMM Multisatellite Precipitation Analysis (TMPA) monthly precipitation products: Initial results, J. Hydrometeor., 17, 777-790, https://doi.org/10.1175/JHM-D-150068.1, 2016.

Marengo, J. A., Nobre, C. A., Tomasella, J., Oyama, M.,. Sampaio, G., Camargo, H., and Alves, L.: The Drought of Amazonia in 2005, J. Climate, 21, 495-516, https://doi.org/10.1175/2007JCLI1600.1, 2008.

Marengo, J. A., Tomasella, J., Alves, L., Soares, W., and Rodriguez, D. A.: The Drought of 2010 in the Context of Historical Droughts in the Amazon Region, Geophys. Res. Lett., 38, 1-5, https://doi.org/10.1029/2011GL047436, 2011.

NASA: GPM-IMERG dataset, available at: http://pmm.nasa.gov/ GPM/, last access: June 2016.

NASA: TRMM Data Downloads, available at: https://pmm.nasa. gov/data-access/downloads/trmm, last access: June 2017.

Paiva, R. C. D., Buarque, D. C., Collischonn, W., Bonnet, M. P., Frappart, F., Calmant, S., and Mendes, C. A. B.: Large scale hydrologic and hydrodynamic modeling of the Amazon River basin, Water Resour Res., 49, 1226-1243, https://doi.org/10.1002/wrcr.20067, 2013.

Schwaller, M. R. and Morris, K. R.: A Ground Validation Network for the Global Precipitation Measurement Mission, J. Atmos. Oceanic Technol., 28, 301-319, https://doi.org/10.1175/2010jtecha1403.1, 2011.

Socio Bosque: http://sociobosque.ambiente.gob.ec/, last access: January, 2012.

Tang, G., Zeng, Z., Long, D., Guo, X., Yong, B., Zhang, W., and Hong, Y.: Statistical and hydrological comparisons between TRMM and GPM level-3 products over a midlatitude basin: Is day-1 IMERG a good successor for TMPA 3B42V7?, J. Hydrometeor., 17, 121-137, https://doi.org/10.1175/jhm-d-150059.1, 2016.

Taylor, K. E.: Summarizing multiple aspects of model performance in a single diagram, J. Geophys. Res., 106, 71837192, https://doi.org/10.1029/2000JD900719, 2001.

Yapo, P. O., Gupta, H. V., and Sorooshian, S.: Multi-objective global optimization for hydrologic models, J. Hydrol., 204, 8397, 1998.

Zubieta, R.,Geritana, A., Espinoza, J. C., and Lavado W.: Impacts of Satellite-based Precipitation Datasets on Rainfall-Runoff Modeling of the Western Amazon Basin of Peru and Ecuador, J. Hydrol., 528, 599-612, https://doi.org/10.1016/j.jhydrol.2015.06.064, 2015.

Zubieta, R., Saavedra, M., Silva, Y., and Giraldez, L.: Spatial analysis and temporal trends of daily precipitation concentration in the Mantaro River basin - Central Andes of Peru, Stochastic Environmental Research and Risk Assessment, 31, 1305-1318, https://doi.org/10.1007/s00477-016-1235-5, 2017.

Zulkafli, Z., Buytaert, W., Onof, C., Manf, B., Tarnavsky, E., Lavado, W., and Guyot, J. L.: A Comparative Performance Analysis of TRMM 3B42 (TMPA) Versions 6 and 7 for Hydrological Applications over Andean-Amazon River Basins, J. Hydrometeorol., 15, 581-592, https://doi.org/10.1175/JHM-D-13-094.1, 2014. 